\title{
KONTRIBUSI TEORI ETIKA AL-GHAZALI UNTUK PENDIDIKAN ORANG DEWASA
}

\author{
Abdul Karim \\ Pascasarjana Universitas Al-Azhar, Kairo, Mesir \\ abdulkarim.19952605@gmail.com \\ DOI: 10.20885/tarbawi.vol13.iss2.art1
}

\begin{abstract}
Akhlak (morality) is one of the three basic frameworks of islamic teachings (akidah, syari'ah and akhlak) which have important position. Moral expression is concrete evidence of the application and embodiment of aqidah and syari'ah, thus, represents the quality of Muslim's faith. This research is a qualitative research conducted with literature study. This study seeks to explain the ethical concept of al-Ghazali and its application in the world of adult education, as explained by al-Ghazali in his works. The author limited the writings of al-Ghazali which are used as the basis for this research study, only to works written in the last years of his life, especially when he lived life as a Sufi. This research found that al-Ghazali divided adult education methods into two, general and specific. The general method applies to everyone and the specific method applies specifically to everyone based on the results of selfintrospection.
\end{abstract}

Keywords: Al-Ghazali; Ethics; Method; Adult Education.

\begin{abstract}
Abstrak
Akhlak adalah satu dari tiga kerangka dasar ajaran Islam (akidah, syari'ah dan akhlak) yang mempunyai kedudukan penting. Wujud akhlak merupakan bukti konkret dari penerapan dan penjiwaan aqidah dan syari'ah, sehingga merupakan gambaran dari kualitas
\end{abstract}




\section{$e^{I-T a r b a w j ~ A b d u l ~ K a r i m ~}$}

keimanan seorang mukmin. Penelitian ini adalah penelitian kualitatif dengan jenis studi pustaka. Penelitian ini berusaha menjelaskan tentang konsep etika al-Ghazali serta aplikasinya dalam dunia pendidikan orang dewasa, sebagaimana yang dijelaskan al-Ghazali dalam karya-karyanya. Karya-karya al-Ghazali yang dijadikan dasar kajian penelitian ini, penulis batasi hanya dari karya-karya yang ditulis pada tahun-tahun akhir hidupnya, khususnya ketika ia menghayati hidup sebagai penganut tasawuf. Peneliti menemukan bahwa al-Ghazali membagi metode pendidikan orang dewasa menjadi dua, umum dan khusus. Metode umum berlaku untuk semua orang dan metode khusus berlaku spesifik pada masing-masing individu berdasarkan hasil introspeksi.

Kata Kunci: Al-Ghazali; Etika; Metode; Pendidikan Orang Dewasa.

\section{Pendahuluan}

Al-Ghazali bernama lengkap Abu Hamid Muhammad Ibn Muhammad Ibn Muhammad al-Ghazali. Ia dilahirkan pada tahun 450 $\mathrm{H}$ atau $1057 \mathrm{M}$ di kota Thus, kawasan Khurasan, Persia. Ayah alGhazali meninggal ketika ia dan adiknya (Ahmad), masih kanakkanak (Al-Jayaland, 2006). Ayahnya mewasiatkan kedua anaknya tersebut untuk belajar kepada temannya, yang dikenal sebagai seorang sufi. Pada masa itu, ia mempelajari al-Qur'an dan hadis, riwayat para wali-wali Allah, beserta keadaan kejiwaan mereka. Al-Ghazali kemudian belajar ilmu hukum Islam di pusat kota Thus kepada guru Ahmad al-Radzkani, dan selanjutnya ke kota Jurjan kepada guru Abu Nashr al-Isma'ily. Kemudian, dalam tiga tahun selanjutnya ia belajar tasawuf di bawah bimbingan Yusuf al-Nassaj dan mulai mendalami keadaan-keadaan jiwa orang-orang saleh, sambil melakukan riyadhah (Al-Jurjani, 2012: 98) guna pemurnian jiwa dan perbaikan akhlaknya. Al-Ghazali lalu pergi ke Nishapur tahun 1077 M untuk belajar ilmu Kalam, Usul Fikih, Filsafat dan Logika dari al-Juwayni yang 
dikenal sebagai Imam al-Haramain, seorang ahli ilmu Kalam paling ternama pada masa itu. Besar sekali kemungkinan, bahwa di bawah bimbingan al-Juwaini, ia juga belajar tasawuf, karena sang imam dulunya murid seorang sufi masyhur yakni Abu Nu'aym al-Ishfahani.

Ketika al-Ghazali sebagai mahasiswa di Nishapur, ia juga sambil berusaha mendalami teori dan praktik tasawuf dari seorang guru yang bernama al-Farmadzi yang menjadi pemimpin kaum sufi disana, di bawah bimbingannya, al-Ghazali melakukan latihan-latihan keras seperti para sufi kebanyakan. Namun, dia tidak mencapai kasyf (AlJurjani, 2012: 154. Kemungkinan besar, menurut Muhammad Abu alQuasem, karena sebab ini, ia kemudian berpaling dari tasawuf dan beralih menggeluti ilmu Kalam dan Filsafat. Tapi dalam era krisisnya tahun $1095 \mathrm{M}$ dia kembali ke dunia tasawuf dan tetap menjadi seorang sufi dan ahli Ilmu Kalam hingga akhir hayatnya (Al-Quasem, 1975: 4).

Al-Ghazali beralih ke jalan tasawuf karena ia yakin bahwa para sufi adalah orang-orang pencari kebenaran yang telah betul-betul mencapai tujuan. Dengan menelaah beberapa karya sufi yang agung, ia mengerti sepenuhnya segala aspek ilmu tasawuf dan menyadari bahwa sesuatu yang khusus dalam ilmu tersebut tidak bisa dipahami dengan penelahaan karya-karya para sufi saja, tapi harus juga lewat pengalaman langsung, dengan jalan perbaikan dan perubahan moral. Ia menyadari dengan jelas, bahwa para sufi bukanlah orang-orang yang suka mengumbar kata-kata (ashâb al-aqwâl) tetapi mereka adalah orang-orang yang nyata berpengalaman (ashâb al ahwâl). Oleh karena itu, yang perlu ia lakukan menurutnya ialah; menghayati kehidupan mereka, berlatih seperti mereka berlatih dan mengesampingkan urusan keduniaan (Al-Quasem, 1975: 7).

Pada saat itu, al-Ghazali telah memiliki kembali keyakinan teguh akan keesaan Allah SWT, kerasulan dan hari akhirat, dan merasa takut yang maha dahsyat akan hari akhirat. Al-Ghazali berpikir, ia tentu akan dihukum di neraka jika ia tidak hidup dalam kesalehan dan yang 


\section{$e^{I-T a r b a w j}$ Abdul Karim}

perlu bagi hidup demikian pikirnya adalah; memutuskan hubungan jiwanya dengan hal-hal duniawi untuk menghadap Allah SWT. Ini hanya dapat dicapai dengan mengesampingkan kekayaan dan kedudukan. Kemudian lari dari segala kegiatan yang membuat waktunya sia-sia.

Ketika masa itu, al-Ghazali mengamati hidupnya, tulisan dan ajarannya dan berpendapat bahwa semua itu tidak ada nilainya dibanding dengan fakta-fakta besar perihal surga dan neraka. Semua itu, menurut Al-Ghazali, diusahakannya demi kejayaan yang sia-sia dan bukan untuk menggapai ridha Allah SWT. Jika ia ingin mengharapkan kebahagiaan abadi di hidup yang akan datang, ia harus mengabdi sepenuhnya kepada Allah SWT sebagai seorang sufi sejati. Karena itu, ia meninggalkan jabatan mahaguru dan seluruh karirnya sebagai pakar ilmu hukum Islam dan ilmu Kalam, melepaskan dirinya dari seluruh kekayaannya, serta merasa tidak bisa hidup secara jujur di masyarakat Baghdad. Al-Ghazali kemudian berangkat menuju Damaskus pada November 1095 M.

Al-Ghazali mengabdikan dirinya pada latihan-latihan seperti para sufi kebanyakan dengan menyepi dan menyendiri. Dia menyibukkan jiwanya dengan menghilangkan sifat-sifat buruk dari dirinya, memperindahnya dengan kebajikan-kebajikan dan mengisi jiwanya dengan zikir kepada Allah, sesuai dengan pengetahuan yang telah didapatnya sebelumnya dari mempelajari tulisan-tulisan beberapa sufi besar. Dengan latihan jiwa yang berat selama sepuluh tahun ia melewati Damaskus, Jerussalem, Hebron, Hijaz, Irak dan Thus. Banyak rahasia yang dibukakan kepadanya selama tahun-tahun itu dan ia menjadi semakin yakin bahwa jalan sufi adalah jalan yang terbaik yang pantas dilalui manusia (Al-Quasem, 1975: 9).

Dalam buku al-Munqidz min al-Dhalâl, sebuah otobiografi yang ditulis oleh al-Ghazali, ia berkata: 
Saya mengetahui dengan pasti bahwa para sufilah yang berjalan di jalan Allah, hidup mereka ialah hidup yang terbaik, cara hidup mereka adalah cara yang paling benar dan watak mereka adalah yang termurni. Sesungguhnya jika kecerdasan para cendekiawan, keahlian orang-orang yang terpelajar dan pengetahuan para ulama perihal kedalaman pengetahuan mereka mengenai ilmu-ilmu agama dihimpun, dalam usaha menyempurnakan kehidupan dan watak para sufi, maka mereka tak akan mampu melakukannya. Karena bagi seorang sufi, semua gerak dan diam secara lahir maupun batin berasal dari penerangan cahaya wahyu kenabian dan selain cahaya wahyu kenabian tidak terdapat cahaya lain di permukaan bumi ini, yang mana dari sana lah ilham dari Allah dapat diterima (Al-Ghazzali, 2004: 299).

Sikap dan pandangan al-Ghazali yang seperti ini terhadap tasawuf dan seorang sufi terus tidak berubah, hingga akhir hayatnya dan ini menurut penulis adalah salah satu faktor terpenting bangunan pemikiran etikanya (Al-Quasem, 1975: 9).

\section{Metode Penelitian}

Penelitian ini menggunakan pendekatan kualitatif. Jenis penelitiannya merupakan penelitian pustaka mengenai pemikiran alGhazali. Menurut Sugiyono, penelitian pustaka merupakan kajian teoritis yang berkaitan dengan budaya, nilai atau norma yang berkembang dalam situasi sosial tertentu (Milyasari dan Asmendri, 2020). Oleh karena itu, objek penelitiannya adalah karya-karya tulis al-Ghazali dengan fokus pada karya-karya yang dihasilkan pada periode akhir hidupnya. Dari data yang diperoleh tersebut, penulis melakukan analisis konten untuk mencapai tujuan penelitian yang dirancang. 


\section{el-Tarbawj Abdul Karim}

\section{Hasil Dan Pembahasan}

\section{Latar Belakang Pembentukan Teori Etika al-Ghazali}

Karya pertama Al-Ghazali yang berbicara tentang etika adalah Maqâshid al-Falâsifah dan Tahâfut al-Falâsifah. Buku Maqâshid al-Falâsifah ditulis antara tahun 484 H/1091 M dan 486 H/1094 M selama periode kurang dari dua tahun, ketika dia mengkaji filsafat pada waktu senggangnya. Karya Al-Ghazali yang terpenting mengenai teori etikanya yang dijelaskannya secara terperinci dan sistematis, adalah karya monumentalnya, Ihyâ 'Ulûm al-Dîn dan Mîzan al-'Amal (Abdullah, 1992: 14-15). Dua buku inilah menjadi fokus perhatian penulis dalam menggali teori etika al-Ghazali beserta penerapannya.

Sepanjang periode sufistik, yang berlangsung sejak keberangkatannya dari Baghdad sampai meninggalnya pada 18 desember $1111 \mathrm{M}$, al-Ghazali telah mengarang karya-karya tentang Etika, yang sebagian besar diakui oleh para ahli, otentik seluruhnya. Ciri-ciri teori etika yang dipaparkan dalam karya-karyanya pada periode ini ada kaitannya dengan latar belakang kehidupannya ketika ia menjalani kehidupan sebagai seorang sufi. Penelaahannya yang mendalam mengenai karya-karya para sufi terdahulu, menimbulkan dalam hatinya suatu kecemasan hebat akan hukuman di hari akhirat, yang membawanya kepada kehidupan menyepi dengan amal ibadah dan riyâdhah.

Jika dilihat dari segi praktis, masalah yang dihadapinya semasa periode sufi ialah mempersiapkan dirinya untuk menghindar dari hukuman Allah SWT dan guna mencapai kebahagiaan di akhirat kelak. Dari segi intelektual, masalahnya adalah untuk menyampaikan pemikiran dan pengalaman kesufiannya kepada orang lain sehingga mereka pun mungkin mencapai tujuan yang sama, sebagaimana yang telah ia capai. Jadi, perhatian utama hidup dan pemikirannya semasa periode sufi ialah untuk memperoleh kehidupan akhirat yang baik. 
Pertimbangan ini menentukan beragam aspek teori etikanya, sehingga teori etikanya bersifat religius dan sufistik.

Teori etika al-Ghazali dapat juga dikatakan bercorak teleologis (aliran filsafat yang mengajarkan bahwa segala sesuatu di dunia ini ada tujuannya). Sebab, ia menilai amal dengan mengacu kepada tujuannya (Al-Quasem, 1975: 13-14). Etika al-Ghazali mengajarkan bahwa manusia punya tujuan yang agung, yaitu kebahagiaan di akhirat. Yakni bahwa amal itu baik, kalau ia menghasilkan pengaruh pada jiwa yang membuatnya menjurus ke tujuan tersebut, dan dikatakan amal itu buruk kalau jiwa terhalangi untuk mencapai tujuan itu (Muslih, 2008: 75).

\section{Sumber-Sumber Teori Etika al-Ghazali}

Sumber pokok teori etika al-Ghazali adalah tulisan-tulisan para sufi sebelumnya. Misalnya Qût al-Qulûb oleh al-Makki, karya-karya alMuhâsibi, berbagai ucapan tersebar (mutafarriqât) oleh al-Junaid, alSyibli, Abu Yazid al-Busthami dan risalah-risalah sufi terkemuka yang lain. Semua buku ini pada dasarnya berkaitan dengan kesejahteraan dan kebahagiaan manusia di hari akhirat (Muslih, 2008: 19).

Paham-paham mereka merupakan dasar bagi pemikiran etika al-Ghazali dan kadang-kala ajaran-ajaran itu langsung dipinjamnya guna membantu menyampaikan maksudnya sendiri dalam karyakaryanya. Namun menurut al-Ghazali, kebanyakan teori etika mereka ini belum lengkap pembahasannya dan kurang bagus penjelasannya. Sebab itu, ia berusaha membangun suatu sistem etika yang lengkap, sistematis dan bebas dari kekurangan tapi tetap menuruti garis yang dianjurkan dalam karya-karya para sufi pendahulunya. Ciri khas karya etika terbesarnya, yakni Ihya 'Ulûm al-Dîn, dilukiskan sebagai berikut:

"Memang benar, bahwa orang-orang terdahulu telah menulis berbagai buku mengenai hal-hal ini, tapi buku ini berbeda 


\section{$e^{I-T a r b a w j}$ Abdul Karim}

dengan semua itu di dalam lima perkara. Pertama, dengan menjelaskan apa yang mereka biarkan kabur dan menerangkan apa yang mereka bicarakan sepintas. Kedua, dengan menyusun apa yang mereka biarkan tidak teratur dan menata kembali apaapa masih yang berserakan. Ketiga, dengan memaparkan apa yang mereka teliti dengan seksama. Keempat, dengan menghapus apa yang mereka ulangi dan memeriksa kembali apa yang mereka catat. Kelima, dengan memperjelas hal-hal yang masih kabur, yang sampai kini tak dapat dipahami dan belum pernah dibahas dalam karya mana pun, karena meski setiap orang telah mengikuti suatu aliran paham, tak ada alasan untuk tidak memperbolehkan seseorang bebas melangkah dan membuka rahasia sesuatu yang belum diketahui."(Al-Ghazali, 1998: 20)

Al-Ghazali dalam menulis karya-karya etikanya banyak mengambil bahan dari kitab-kitab suci seperti Al-Qur'an, Injil, Taurat, Zabur dan shuhuf Ibrahim dan hadis Nabi Muhammad Saw. Dari semua kitab suci tersebut, Al-Qur'an yang paling banyak dia ambil. Pengetahuan perihal hadis dia dapatkan dari karya-karya sufi, khususnya Qût al-Qulûb al-Makki, yang memuat banyak sekali hadis nabi.

Al-Ghazali juga menurunkan paham-paham etikanya dari karya-karya para filsuf tentang etika. Pada zamannya, karya-karya ini terdapat dua macam. Pertama, terjemahan dari karya-karya filsuf Yunani tentang filsafat moral, seperti, Aristoteles dan Galen. Kedua, yaitu buku-buku para filsuf muslim dan beberapa penerjemah Kristen, seperti Yahya ibn 'Adi dan Qustha ibn Luqa. Al-Ghazali sendiri mengatakan, bahwa buku-buku al-Farabi dan Ibn Sina sudah dikajinya secara mendalam (Al-Quasem, 1975: 20-21).

\section{Konsep Etika Al-Ghazali}

Sisi paling menonjol dari tujuan pemikiran etika al-Ghazali terpusat pada kebahagiaan nasib individu di akhirat kelak. Tujuan etika al-Ghazali ini begitu jelas diterangkannya dalam bukunya Mîzân 
al-'Amal (Al-Ghazali, 2012: 87). Oleh karena itu, menurut Amin Abdullah, al-Ghazali belum menjelaskan bangunan teori etikanya dari pendekatan sosiologi, psikologi ataupun antropologi dan sejenisnya. Kalaupun terdapat pendekatan ataupun pemahaman yang mirip seperti itu, hal itu bukan merupakan komitmen yang menjadi perhatiannya sejak awal. (Abdullah, 1992: 261-262).

Istilah khulûq sudah ada jauh sebelum al-Ghazali berbicara tentang etika dalam karya-karyanya. Dalam sebuah hadis Rasulullah pernah bersabda "sesungguhnya aku diutus untuk menyempurnakan budi pekerti (akhlak) yang baik". Ibnu Miskawaih juga telah menulis buku khusus yang berbicara tentang etika, yang berjudul Tahdzîb alAkhlâq. Buku ini penjelasannya hampir menyerupai buku-buku ilmu etika atau filsafat moral yang ditulis oleh para filsuf Yunani, yang selanjutnya diikuti oleh beberapa filsuf muslim (Mubarok, 2012: 159).

Adapun akhlak menurut pandangan al-Ghazali, bukanlah pengetahuan (ma'rifah) tentang baik dan buruk, bukan pula kemampuan (qudrah) untuk melakukan sesuatu yang baik dan buruk, bukan pula hanya sekadar perbuatan ( $\left.f^{\prime} i l\right)$ yang baik dan buruk, melainkan suatu keadaan jiwa yang mantap atau stabil. Pengertian akhlak mengenai menurut al-Ghazali ini terdapat dalam Ihyâ 'Ulûm alDîn, yang berbunyi:

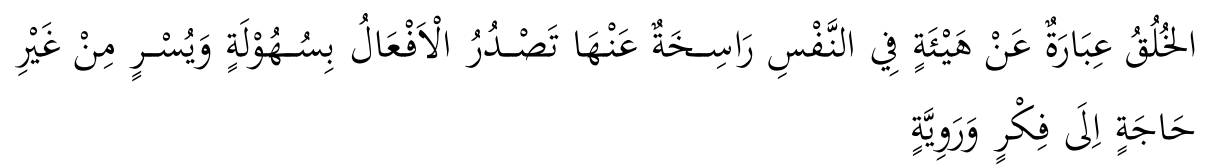

"Akhlak berarti suatu kemapanan keadaan jiwa yang menghasilkan perbuatan dengan mudah, tanpa harus direnungkan dan disengaja." (AlGhazali, 1998: 84).

Dari definisi diatas jelas terbaca, bahwa ada dua keadaan jiwa yang harus terpenuhi sehingga sesuatu dapat disebut akhlak. Keadaan jiwa yang pertama adalah stabilitas atau kemapanan. Misalnya, 


\section{$e^{I-T a r b a w j ~ A b d u l ~ K a r i m ~}$}

seseorang yang berakhlak pemurah atau dermawan, ialah orang yang kemauannya untuk mendermakan kekayaannya telah menjadi mapan dan relatif permanen dalam jiwanya. Seorang yang jarang berderma, yang kalaupun melakukannya, hanya karena adanya faktor-faktor luar, tidak dapat dikatakan sebagai seoorang yang berakhlak pemurah atau dermawan. Syarat kedua ialah timbulnya tindakan-tindakan yang mudah dan spontan dari suasana jiwa yang telah mapan. Karena itu, seseorang pemurah ialah orang yang mendermakan hartanya dengan mudah dan tanpa paksaan.

Bagi al-Ghazali, akhlak yang baik adalah yang berada antara dua kutub ekstrem, yakni berada di pertengahan. Kemudian timbullah pertanyaan, bagaimana mengetahui suatu perbuatan disifati baik? Menurut al-Ghazali sifat pertengahan ialah yang telah ditetapkan oleh akal dan syariat. Al-Ghazali berpendapat bahwa alasan pokok untuk memperhatikan jalan pertengahan itu ialah; fakta bahwa manusia hanya bisa mencapai kebahagiaan di akhirat, karena ketika meninggal jiwa manusia memiliki sifat malaikat, yakni substansinya adalah identik dengan zat malaikat dan alam asalnya ialah alam malaikat. Hanya jiwa yang bebas dari ikatan inilah yang diampuni. Karena AlQur'an berkata, "tak seorang pun diampuni kecuali dia yang datang kepada Allah dengan jiwa yang bebas." Jiwa manusia hanya dapat dibebaskan dengan mempertahankan jalan pertengahan.

Al-Ghazali menjelaskan ini dengan contoh-contoh. Misalnya orang yang berwatak kikir menyibukkan dirinya dengan menimbun harta dan orang yang berwatak boros sibuk dengan selalu membelanjakan harta. Dalam mencapai kemerdekan dari ikatan duniawi, orang harus bebas dari kedua sifat berlebihan ini, baik terlampau boros membelanjakan atau sebaliknya menimbun harta dunia. Tapi karena hal ini secara manusiawi tidaklah mungkin, dia harus mencapai apa yang terdekat dan hampir serupa dengan itu, dan ini dapat dicapai dengan cara; menjaga sikap pertengahan dalam 
berbelanja. Jiwa seseorang yang selalu berada di jalan pertengahan dalam mengeluarkan harta boleh dikatakan bebas dari kedua sifat cinta harta tersebut, persis seperti air hangat suam-suam kuku yang tidak terlalu panas dan juga tidak terlalu dingin.

Jika manusia selalu berusaha untuk bersikap pertengahan dalam semua urusan, jiwanya tak akan punya kaitan pada benda duniawi mana pun. Kata al-Ghazali, dengan alasan inilah maka syariat memerintahkan kondisi jiwa pertengahan ini. Dia juga berpendapat, bahwa tidak mungkin orang senantiasa selalu berada di jalan pertengahan. Oleh sebab itu, tidak seorang pun akan terhindar dari penderitaan di akhirat. Dia memberi penjelasan dengan menyatakan, bahwa jalan pertengahan itu ialah jalan lurus yang diperintahkan alQur'an untuk ditaati oleh manusia, tapi jalan itu sukar sekali diikuti. Manusia hanya dapat mendekatinya tetapi tidak dapat mencapainya.

\section{Mungkinkah Akhlak Diubah?}

Sebelum menjelaskan metode perbaikan akhlak, al-Ghazali dalam kitabnya Ihyâ 'Ulûm al-Dîn lebih dahulu menegaskan pandangannya bahwa perubahan akhlak itu adalah mungkin sepanjang ia melalui usaha dan latihan moral yang sesuai. Al-Ghazali menyangkal pandangan beberapa pendahulunya yang menafikan kemungkinan perubahan sifat pembawaan manusia. Menurut alGhazali, fungsi agama Islam yang utama, ialah membimbing manusia memperbagus akhlaknya .Jika akhlak tidak dapat diubah, maka semua perintah, teguran, anjuran dan ancaman agama akan tidak berguna sama sekali. Rasulullah Saw telah bersabda: perbaguslah akhlak kalian!". Jika perubahan akhlak seorang manusia tidak mungkin, maka tidak mungkin umat Islam diperintahkan untuk memperbagus akhlaknya, baik akhlak individu secara khusus atau akhlak masyarakat secara lebih luas. 


\section{$e^{I-T a r b a w j}$ Abdul Karim}

Kemudian, hampir setiap orang mengakui, bahwa perubahan sifat pada hewan saja mungkin. Binatang seperti singa umpamanya, sifatnya bisa diubah dari buas menjadi jinak. Jika ini mungkin, apalagi perbaikan akhlak manusia yang dikaruniai akal oleh Allah.

Al-Ghazali menyatakan bahwa perubahan akhlak tidak menuntut agar pembawaan hawa nafsu dan amarah yang terdapat dalam diri setiap manusia dihilangkan sama sekali atau ditindas, karena hal ini tidak mungkin selama manusia masih hidup. Perubahan hanya menghendaki pengendalian hawa nafsu dan amarah kepada keadaan pertengahan. Pengalaman hidup telah membuktikan, bahwa hal itu mungkin terjadi dengan jalan latihan dan pendidikan moral yang baik. Akan tetapi kecepatan perubahan itu berbeda atau tidak sama pada setiap orang. Al-Ghazali menjelaskan perbedaan ini dengan membagi manusia pada empat macam menurut cepatlambatnya akhlak seseorang dapat diubah (Al-Ghazali, 2012: 56).

Pertama, terdiri dari orang-orang yang lengah, yaitu mereka yang belum dapat membedakan antara perkara hak dengan perkara batil, dan antara sesuatu yang baik dengan sesuatu yang buruk. Orang-orang macam ini masih terbebas dari kehendak untuk mengikuti hawa nafsu. Nafsu jasmani mereka tidak terlalu kuat, karena mereka tidak memperturutkannya. Akhlak seseorang yang semacam ini, dapat menjadi baik dalam waktu singkat jika dididik dengan benar. Orang semacam ini hanya membutuhkan kepada guru pembimbing dan hal-hal yang mendorong dirinya kepada kebenaran dan kebaikan

Kedua, ialah mereka yang tahu tentang keburukan, tapi tidak menjauhkan diri darinya, sebab dia merasa perbuatan burukya itu nikmat untuk dilakukan. Perbaikan akhlak seseorang yang seperti ini, lebih sukar daripada yang ditingkat pertama, tetapi masih mungkin diperbaiki dengan upaya yang lebih giat. 
Ketiga, mereka yang meyakni bahwa perilaku buruk (menurut syariat dan akal) yang mereka perbuat adalah benar dan baik, dan mereka menuruti jalan yang tercela itu dengan sepenuh hati. Akhlak orang-orang yang tergolong macam ini hampir tidak mungkin diubah.

Keempat, ialah mereka yang selain terbiasa berperilaku buruk, juga mengganggap baik dan merasa bangga dengan perbuatan buruk yang mereka kerjakan. Mereka ini yang paling sukar akhlaknya untuk diubah menjadi lebih baik.

Orang-orang pada tingkatan pertama disebut oleh al-Ghazali sebagai orang-orang bodoh (jâhil) yang ditingkat kedua, bodoh dan tersesat (dhâll) yang di tingkat ketiga bodoh, tersesat dan jahat (fâsiq) dan di tingkat keempat bodoh, tersesat jahat dan bandel (syarîr) (AlGhazali, 2012: 57).

\section{Metode Perbaikan Akhlak untuk Orang Dewasa}

Setelah menegaskan bahwa akhlak bisa diubah, al-Ghazali selanjutnya menyarankan cara melaksanakan perbaikannya. Sepanjang penelaahan penulis pribadi terhadap Ihyâ 'Ulûm al-Dîn dan Mîzân al-'Amal, penulis membagi dua metode al-Ghazali untuk mendapatkan akhlak yang baik, yakni umum dan khusus. Pertama, metode umum atau yang secara umum bisa dapat ditempuh setiap orang. Kedua, metode khusus, yakni metode mandiri untuk mengenali atau mencari-cari aib diri sendiri secara lebih mendalam, karena objek yang diperbaikinya adalah hal yang ada di dalam diri, yakni hati pribadi.

\section{Metode Umum}

Pertama, ada beberapa orang memang memiliki akhlak yang baik secara alamiah, sebagai sesuatu pemberian Allah kepada mereka sewaktu dilahirkan.Mereka diciptakan dengan semua pembawaan jiwa yang sudah dalam keadaan seimbang. Pembawaan nafsu dan 


\section{$e^{I-T a r b a w j}$ Abdul Karim}

amarah mereka mematuhi perintah akal dan syariat, sehingga akhlak mereka adalah baik secara alamiah. Contohnya orang-orang pada golongan ini ialah para nabi dan rasul. Selain para nabi dan rasul, secara logis memungkinkan adanya orang yang secara alamiah telah memiliki akhlak yang baik semenjak dilahirkan.

Kedua, untuk mencapai akhlak yang baik, menurut al-Ghazali ialah dengan menempuh jalan yang paling umum, yakni mujâhadah dan riyâdhah yakni; bersusah-susah secara sengaja melakukan perbuatan yang baik untuk mencapai akhlak yang baik, sehingga perbuatan yang baik tadi, menjadi kebiasaan dan sesuatu perbuatan yang menyenangkan. Misalnya untuk memperoleh akhlak dermawan, seseorang perlu bersusah-susah melakukan perbuatan seperti seorang dermawan, misalnya mendermakan beberapa harta miliknya, dan terus-menerus tekun berprilaku demikian, sehingga menjadi semacam kebiasaan yang stabil dalam dirinya.

Suatu perbuatan seseorang dapat dikatakan menjadi akhlak, jika dia merasa senang melakukannya. Oleh karena itu, mencapai rasa senang ialah salah satu kriteria untuk memperoleh suatu akhlak yang baik. Umpamanya, seseorang hanya dapat dikatakan memiliki akhlak pemurah jika ia sudah merasa nikmat dan senang mendermakan hartanya. Metode ini dipandangnya sebagai cara yang paling efektif untuk mencapai sifat jiwa yang baik.

Ketiga, akhlak yang baik dapat pula diperoleh dengan memperhatikan orang-orang baik dan bergaul dengan mereka. Secara alamiah, manusia adalah peniru akhlak seseorang dan tanpa sadar bisa tertular kebaikan dan keburukan dari orang lain. Jika seseorang bergaul dengan orang-orang yang saleh agak lama, dengan tidak sadar akan tumbuh dalam dirinya sendiri beberapa akhlak atau sifat baik yang dimiliki oleh orang-orang baik atau saleh tersebut.

Keempat, jika langkah ketiga tidak dapat dilaksanakan, sebab tidak adanya orang-orang saleh di sekitarnya. Maka penelaahan 
kehidupan mereka melalui buku-buku, sudah memadai untuk menguatkan keinginan memperoleh akhlak-akhlak yang baik dan memudahkan pembinaannya. Inilah sebabnya, dalam membahas sifat-sifat terpuji dan sifat-sifat tercela, al-Ghazali sering menceritakan kisah orang-orang saleh yang mengalami perjuangan moral dan juga menganjurkan menelaah kitab Hilyât al-Awliya, yang mengisahkan seluk-beluk kehidupan para sahabat, para pengikut mereka dan orang-orang saleh (Al-Quasem: 1975: 20-21).

\section{Metode Khusus}

Metode khusus yang dimaksud penulis disini adalah, mengenali aib diri pribadi. Ketika seseorang mengenal aib diri sendiri, mata hatinya akan terbuka dan akan memudahkannya untuk memperbaikinya. Seumpama penyakit lahiriah yang ditangani seorang dokter, tentunya sebelum dokter menentukan obat yang akan diminum pasien dan dosis yang diperlukan, terlebih dahulu dokter tersebut mencoba mencari tahu jenis dan penyebab penyakitnya, yang nantinya akan mempermudah pengobatan pasien tersebut. Begitupun penyakit hati. Menurut al-Ghazali, ada empat cara untuk mengenali aib atau kelemahan pada diri sendiri.

Pertama, hendaknya menemui seorang guru yang mampu mengenali kelemahan-kelemahan jiwa, mampu melihat sifat-sifat buruk yang tersembunyi dan mengenali dirinya sendiri serta mengikuti perintah-perintahnya dalam perjuangan melawan hawa nafsu.Namun orang semacam ini sangat sulit ditemukan pada zaman sekarang.

Kedua, didampingi seorang sahabat sejati yang benar-benar jujur mau menunjukkan segala sifat buruknya yang terlihat maupun yang tak terihat. Cara inilah yang ditempuh oleh Khalifah Umar bin Khattab yang sering berkata, "semoga Allah mengasihi orang yang mau menunjukkan kesalahan-kesalahanku." Orang yang seperti ini pun sangat sulit untuk didapatkan untuk zaman sekarang. 


\section{$e^{I-T a r b a w j ~ A b d u l ~ K a r i m ~}$}

Ketiga, mengambil pelajaran dari orang-orang yang membenci dan memusuhi kita. Sebab orang yang membenci biasanya akan jujur mengungkapkan keburukan-keburukan seseorang yang dibencinya. Meskipun kecenderungan manusia umumnya mengingkari ucapan orang-orang yang memusuhinya dengan menganggap kata-katanya muncul sebagai rasa dengki, maka semestinya bagi orang yang mempunyai hati yang bersih ia akan berterima kasih karena dengan demikian keburukan-keburukan yang dimilikinya dapat diketahui dan mempermudahnya untuk memperbaikinya.

Keempat, bergaul dengan masyarakat dan setiap keburukan yang dijumpainya pada masyakarat dapat dijadikan introspeksi diri bagi dirinya sendiri, seolah-olah keburukan itu melekat pada dirinya. Seperti disebutkan dalam sebuah hadis nabi, "sesungguhnya seorang mukmin merupakan cermin bagi mukmin lain." Sehingga melalui orang lain kita dapat melihat aib sendiri dan menyadari bahwa sifat manusia itu tidak jauh antara yag satu dengan yang lainnya, tidak jauh berbeda dalam hal memperturutkan hawa nafsu (Al-Ghazali, 1998: 101-103).

Kesimpulan

Al-Ghazali mendefinisikan istilah akhlak secara filosofis, dan meletakkan ukuran-ukuran suatu perbuatan bisa disebut sebagai akhlak (budi pekerti).Menurut al-Ghazali, akhlak (budi pekerti) manusia mungkin untuk diubah.Oleh karena itu, al-Ghazali membagi manusia menurut cepat-lambatnya akhlaknya untuk diubah. Bagi orang dewasa, metode pendidikan lebih ditekankan lewat pembiasaan, atau pengulangan suatu perbuatan hingga perbuatan itu menjadi watak. Melalui penelaahan penulis pribadi terhadap kitab Ihyâ 'Ulûm al-Dîn, penulis berkesimpulan bahwa perwujudan metode perbaikan akhlak untuk orang dewasa dapat dibagi kepada dua metode, yakni; metode umum dan khusus. Pertama, metode umum, akhlak (budi pekerti) seseorang bisa menjadi baik dengan; 1) karunia tuhan 2) mujâhadah dan riyâdhah 3) bergaul dengan orang saleh dan 4) 
penelaahan bacaan-bacaan mengenai orang-orang saleh.Kedua, metode khusus, yakni dengan pengenalan terhadap aib diri sendiri, dengan empat cara: 1) berguru kepada seorang mursyid yang mampu mengenali sifat-sifat buruk yang terdapat dalam dirinya; 2) meminta seorang sahabat sejati yang jujur, dan mau menunjukkan segala sifat yang buruknya; 3) mengambil pelajaran dari orang-orang yang membenci dan memusuhinya; 4) bergaul dengan masyarakat dan setiap keburukan yang dijumpainya pada masyakarat dapat dijadikan introspeksi diri bagi dirinya sendiri, seolah-olah keburukan itu melekat juga pada dirinya.

\section{Daftar Pustaka}

Abdullah, Muhammad Amin. (1992). The Idea of Universality of Ethical Norms in Al-Ghazali and Immanuel Kant. Ankara: Kotlu Doguma Armagan.

Al-Ghazali, Abu Hamid. (1998). Ihya 'Ulum ad-Din. Alepo: Dâru al-Wa'y.

Al-Ghazali, Abu Hamid. (2004). Al-Munqidz min adh-Dhalâl. Kairo, Maktabah al-Imân.

Al-Ghazali, Abu Hamid. (2012). Mîzân al-'Amal. Beirut, alMaktabah al-'Ashriyyah.

Al-Jalayand, Muhammad as-Sayyid. (2006). Al-Imam al-Ghazâli dirâsât wa buhûts. Kairo, Dâr al-Hâni.

Al-Jurjâni, 'Ali ibn Muhammad as-Sayyid asy-Syarif. (2012). AtTa' rîfât. Kairo, Dâru al-Fadhîlah.

An-Najjâr, 'Ammâr, (1992). Nadzhôrôt fî fikr al-Ghozâli. Kairo, Dar al-Ma'ârif.

Al-Quasem, Muhammmad Abu. (1975). The Ethics of al-Ghazali: A Composite Ehics in Islam. Kuala Lumpur: Caravan Book.

Badawy, Abdurrahman. (1977). Mu'allafât al-Ghazâli. Kuwait, Wakâlat al-Mathbû'ât.

Bertens, K. (2013). Etika. Yogyakarta: Kanisius. 


\section{$e^{I-T a r b a w j}$ Abdul Karim}

Ibrahim ibn Isma'il. (Tanpa Tahun). Syarh Ta'lîm al-Muta'allim. Jakarta:,Dâr al-kutub al-Islamiyah.

Iqbal, Abu Muhammad. (2013). Konsep Pemikiran al-Ghazali tentang Pendidikan. Madiun: Jaya Star Nine.

Milyasari dan Asmendri. (2020). Penelitian Kepustakaan (Library Research) dalam Penelitian Pendidikan IPA. Natural Science: Jurnal Penelitian IPA dan Pendidikan IPA. Vol. 6, No. 1.

Mubarak, Zaki. (2012). Al-Akhlaq 'Inda al-Ghazali. Kairo, Kalimat 'arabiyyah li al-tarjamah wa al-Nasyr.

Muslih, Muhammad. (2008). Pengantar Filsafat. Ponorogo: Darussalam University Press.

Thanthawi, Muhammad Sayyid. (2000). Al-'Aqīdah wa al-Akhlak. Mesir: Nahdhatu Mishra. 